\title{
An analysis of carbon monoxide poisoning cases in Bursa, Turkey
}

\author{
S.. Akköse, ${ }^{1}$ N. Türkmen, ${ }^{2}$ M. Bulut, ${ }^{1}$ S. Akgöz, ${ }^{3}$ R. İscimen ${ }^{4}$ and B. Eren ${ }^{2}$
}

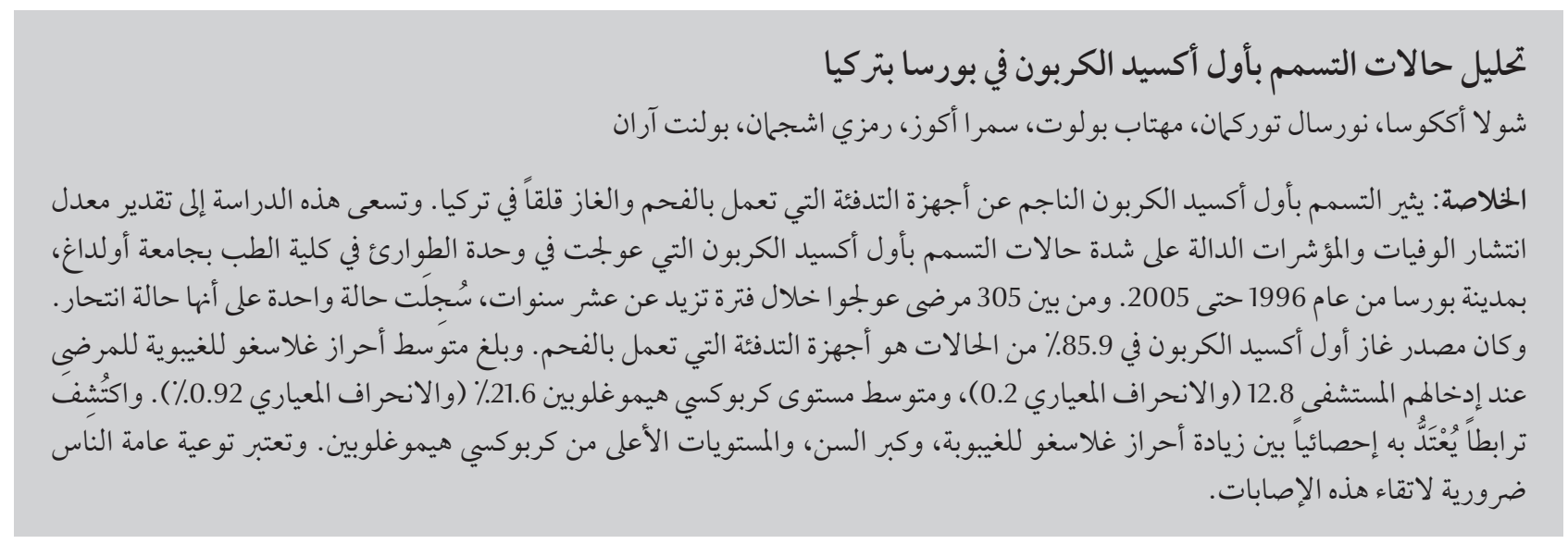

ABSTRACT Carbon monoxide (CO) poisoning from coal and gas heaters is a public health concern in Turkey. This study estimated the prevalence, mortality rate and clinical predictors of severity of CO poisoning cases treated at the emergency unit of the Uludağ University Medical School, Bursa from 1996 to 2006. Of 305 patients treated over a 10-year period, only 1 case was recorded as suicide. The CO source was a coal heater in $85.9 \%$ of cases. Mean Glasgow coma score (GCS) on admission was 12.8 (SD 0.2) and mean carboxyhaemoglobin level was $21.6 \%$ (SD 0.92\%). There were statistically significant associations between higher GCS score, older age and higher $\mathrm{HbCO}$ level. Better education of the public is vital for the prevention of these injuries.

\begin{abstract}
Analyse des cas d'intoxication au monoxyde de carbone à Bursa (Turquie)
RÉSUMÉ L'intoxication au monoxyde de carbone (CO) due à des appareils de chauffage au charbon et au gaz est un problème de santé publique en Turquie. Cette étude a estimé la prévalence, le taux de mortalité et les facteurs cliniques prédictifs de la gravité des cas d'intoxication au CO traités au service des urgences de l'hôpital de la faculté de médecine de l'université Uludağ de Bursa entre 1996 et 2005. Sur 305 patients traités au cours des dix années, un seul cas a été enregistré comme étant un suicide. Le CO était émis par un appareil de chauffage au charbon dans 85,9 \% des cas. Le score de Glasgow moyen au moment de l'admission était de 12,8 (E.T. 0,2) et le niveau moyen de carboxyhémoglobine (HbCO), de 21,6 \% (E.T. 0,92\%). II existait des associations statistiquement significatives entre un score de Glasgow élevé, l'âge et un niveau de carboxyhémoglobine élevé. Il est indispensable de mieux informer le public si l'on veut éviter ce type de traumatisme.
\end{abstract}

${ }^{7}$ Department of Emergency Medicine; ${ }^{2}$ Department of Forensic Medicine; ${ }^{3}$ Department of Biostatistics; ${ }^{4}$ Department of Anaesthesiology, Uludağ University Medical School, Bursa, Turkey (Correspondence to B. Eren: bulenteren2000@yahoo.com).

Received: 30/05/07; accepted: 27/09/07 


\section{Introduction}

Carbon monoxide (CO) is a colourless, odourless, tasteless and nonirritant gas. The major source of $\mathrm{CO}$ in the environment is incompletely burned organic material. Common exposures include smoke from fires and barbecues, wood or coal heaters that burn with inadequate oxygen, incomplete burning of butane or methane used in lighting and heaters, exhaust gases from motor vehicles and cigarette smoke $[1,2]$.

While CO inhalation is a common method of suicide in some countries, in Turkey most deaths caused by $\mathrm{CO}$ poisoning result from accidents. Especially in the winter months, leaks from coal heaters are the major culprits [3-6]. Although these deaths can be prevented with simple measures, they still persist.

$\mathrm{CO}$ poisoning is a serious concern in Bursa, which is located in the northwest part of Turkey in the southern Marmara region where approximately 4 million people reside [7]. Bursa, with a population of 2.2 million, is the largest city in the region [7]. Especially during periods of south-east wind in the winter months, coal heaters become instruments of death. Every year, approximately 900 people suffer $\mathrm{CO}$ poisoning. Approximately $80 \%$ of these patients are treated at outpatient clinics, the rest are hospitalized [8]. According to the records of the Bursa Forensic Institute, in the last 10 years, 211 patients died of $\mathrm{CO}$ poisoning due to accidents in the home or workplace.

This study was carried out to reveal the prevalence, mortality rate and clinical predictors of the severity of $\mathrm{CO}$ poisoning in patients treated at the emergency unit of the Uludağ University Medical School.

\section{Methods}

This study was a retrospective review of records of cases of $\mathrm{CO}$ poisoning treated between 1 January 1996 and 1 January 2006 at the emergency unit of the Uludağ University Medical School in Bursa, Turkey. Not all poisonings occurring in Bursa are referred to Uludağ Medical School Hospital for treatment; the intensive care unit (ICU) of the Uludağ Medical School Hospital has a limited number of beds and 3 public hospitals in Bursa also receive poisoning cases. The study was originally planned as a collaborative project, but the records of the public hospitals were incomplete and they were not included.

A data collection form was designed and data were compiled retrospectively. The admission records of the emergency unit, the ICU files and the patient charts were examined. There are 2 separate emergency units in our hospital: paediatric and adult. During the period of the study patients aged 14 years and over were treated in the adult emergency unit and it was decided to exclude younger patients. The following data were collected for patients: age; sex; source of $\mathrm{CO}$; Glasgow coma score (GCS) at admission [9]; symptoms at admission; and blood carboxyhaemoglobin ( $\mathrm{HbCO}$ ) level at admission measured using a blood gas analyser (Omni S, Roche Diagnostics, Indianapolis, USA). The severity of CO poisoning was graded with respect to the GCS as: mild (GCS 15), moderate (GCS 13-14) and severe $(\mathrm{GCS} \leq 12)$. Outcome variables collected were: whether treated in emergency unit or admitted to ICU; duration of stay in the ICU (days); need for and duration of mechanical ventilation (days); and death.

It should be noted that the $\mathrm{HbCO}$ levels were not evaluated properly in the initial years of the study and thus records for this period were incomplete. Also the central record office in the hospital was not established until 2006.

\section{Statistical analysis}

Statistical analysis was performed using SPSS, version 11.0 for Windows. The results were expressed as mean and standard deviation (SD), median (interquartile range; 25 th-75th percentiles) and frequency, as appropriate. One-sample chi-squared test and Pearson chi-squared test were used in the comparison of categorical variables. The Kruskall-Wallis test and the MannWhitney U-test were used for comparison of the distributions of continuous variables. Correlations were determined by Spearman rank correlation analysis. The clinical predictors of the severity of $\mathrm{CO}$ poisoning were identified by multivariate logistic regression analysis. All statistical analyses were performed according to 2-sided hypothesis tests and a $P$-value $<0.05$ was considered statistically significant.

\section{Results}

\section{Characteristics of patients and poisonings}

The total number of patients in the 10year period was 305 . Their mean age was 36.8 (SD 16.2) years (range 14-79 years) and approximately half of the patients $(152,49.8 \%)$ were between 20 and 40 years old; 174 patients (57.0\%) were women and 131 (43.0\%) were men $(P=0.014)$ (Table 1$)$.

Except for 1 suicide attempt, all poisonings (304 patients, 99.7\%) were reported as being due to accidents. The source of CO was a coal heater in 262 patients (85.9\%), a liquefied gas heater in $41(13.4 \%)$ and motor vehicle exhaust in $2(0.7 \%)$ (Table 1$)$.

The main symptoms at admission in the mild poisoning cases $(n=180)$ were headache $(32.9 \%)$, fatigue $(30.6 \%)$, nausea (19.1\%) and dizziness (13.3\%) (Table 1).

The mean GCS at admission was 12.8 (SD 0.2) (range 3-15). According to our GCS classification, 180 


\begin{tabular}{|c|c|c|}
\hline Characteristic & No. & $\%$ \\
\hline \multicolumn{3}{|l|}{ Sex } \\
\hline Male & 131 & 43.0 \\
\hline Female & 174 & 57.0 \\
\hline \multicolumn{3}{|l|}{ Age group (years) } \\
\hline 14-19 & 37 & 12.1 \\
\hline $20-29$ & 88 & 28.9 \\
\hline $30-39$ & 64 & 21.0 \\
\hline $40-49$ & 46 & 15.1 \\
\hline $50-59$ & 33 & 10.8 \\
\hline$\geq 60$ & 37 & 12.1 \\
\hline \multicolumn{3}{|l|}{ Cause } \\
\hline Accident & 304 & 99.7 \\
\hline Suicide & 1 & 0.3 \\
\hline \multicolumn{3}{|l|}{ Source of $\mathrm{CO}$} \\
\hline Coal heater & 262 & 85.9 \\
\hline Liquefied gas heater & 41 & 13.4 \\
\hline Motor vehicle exhaust & 2 & 0.7 \\
\hline \multicolumn{3}{|l|}{ Glasgow coma score } \\
\hline Severe $(\leq 12)$ & 83 & 27.2 \\
\hline Moderate (13-14) & 42 & 13.8 \\
\hline Mild (15) & 180 & 59.0 \\
\hline \multicolumn{3}{|c|}{ Blood HbCO level $(\%)(n=188)$} \\
\hline $0-9$ & 33 & 17.6 \\
\hline $10-19$ & 62 & 33.0 \\
\hline $20-29$ & 54 & 28.7 \\
\hline 30-39 & 21 & 11.1 \\
\hline $40-49$ & 11 & 5.9 \\
\hline $50-59$ & 5 & 2.7 \\
\hline$\geq 60$ & 2 & 1.0 \\
\hline \multicolumn{3}{|c|}{ Symptoms at admission $(n=173)^{a}$} \\
\hline Headache & 57 & 32.9 \\
\hline Fatigue & 53 & 30.6 \\
\hline Nausea & 33 & 19.1 \\
\hline Dizziness & 23 & 13.3 \\
\hline Syncope & 15 & 8.7 \\
\hline Blurred vision & 6 & 3.5 \\
\hline Urinary incontinence & 1 & 0.6 \\
\hline
\end{tabular}

${ }^{a}$ Only for patients with mild symptoms (Glasgow coma score 15); there was more than 1 symptom for some patients.

$\mathrm{HbCO}=$ carboxyhaemoglobin

patients (59.0\%) had mild CO poisoning (GCS15), 42(13.8\%) hadmoderatepoisoning (GCS13-14)and83(27.2\%) had severe poisoning $(\mathrm{GCS} \leq 12)$ (Table 1$)$.
As to seasonal distribution, 197 $(64.6 \%)$ poisonings occurred in the winter, 75 (24.6\%) in spring, 29 (9.5\%) in autumn and $4(1.3 \%)$ in the summer. The number of cases increased significantly after $2001(P<0.001)$ with the majority occurring in the winter $(P<$ 0.001) (Figure 1).

\section{Outcome}

One-quarter of the patients $(74,24.3 \%)$ were admitted to the ICU and 46 of them $(62.2 \%)$ required mechanical ventilation. The mean duration of ICU stay was 11.2 (SD 15.8) days (range 1-79 days). The mean duration of mechanical ventilation was 8.5 (SD 10.5) days (range 1-57 days). Of the 231 patients not admitted to the ICU, 180 (77.9\%) were treated at the emergency unit and discharged and 44 (19.0\%) were referred to another hospital. Poisoning was graded severe in 41 (89.1\%) of the 46 patients who required mechanical ventilation and $57(77.0 \%)$ of the 74 patients admitted to the ICU. A total of 10 patients died (3.3\%), all were cases of severe poisoning: 7 in the ICU and 3 patients after treatment in the emergency unit.

\section{Risk factors}

When the association of the GCS with the duration of mechanical ventilation, ICU stay and $\mathrm{HbCO}$ levels were investigated highly significant but weak negative correlations were found. As GCS decreased, there was longer duration of mechanical ventilation, longer ICU stay and higher HbCO levels $(r=-0.499, r$ $=-0.452$ and $r=-0.260$ respectively, $P$ $<0.001$ ) (Table 2). There was a statistically significant but weak negative association between age and $\mathrm{HbCO}$ level $(r=-0.147, P<0.045)$ (Table 2).

Of patients aged $\geq 60$ years, $54.1 \%$ (20/37) had severe CO poisoning; in the other age groups, the frequency of mild poisoning varied between $54.1 \%$ and $69.6 \%(P<0.001)$. The source of mild CO poisoning was a coal heater in 


\begin{tabular}{|c|c|c|c|c|}
\hline \multirow[t]{2}{*}{ Variable } & $\begin{array}{l}\text { Glasgow coma } \\
\text { score }\end{array}$ & $\begin{array}{l}\text { Duration of } \\
\text { mechanical } \\
\text { ventilation }\end{array}$ & $\begin{array}{l}\text { Duration of stay } \\
\text { in ICU }\end{array}$ & Blood HbCO level \\
\hline & $r$ & $r$ & $r$ & $r$ \\
\hline Age & NS & NS & NS & $-0.147^{*}$ \\
\hline Glasgow coma score & - & $-0.499^{* *}$ & $-0.452^{* *}$ & $-0.260^{* *}$ \\
\hline Duration of mechanical ventilation & - & - & $0.795^{* *}$ & NS \\
\hline Duration of ICU stay & - & - & - & NS \\
\hline
\end{tabular}

\section{$62.2 \%$ of patients $(P<0.05)$. The $\mathrm{HbCO}$}

level was significantly higher $(P<0.01)$ and the duration of ICU stay significantly longer $(P<0.01)$ in severe poisoning cases compared with mild and moderate poisoning cases (Table 3).

Although more cases were due to coal-fired heaters, the poisoning was more severe in terms of GCS in patients poisoned by liquefied gas sources than by coal heaters (Table 3).

\section{Regression analysis}

In univariate logistic regression analysis where $\mathrm{CO}$ poisoning (severe versus moderate/mild) was the dependent variable, age $\geq 60$ years old significantly increased the likelihood of having severe CO poisoning compared with age $\leq 19$ years $(\mathrm{OR}=4.3$; $95 \% \mathrm{CI}: 1.5-11.8)$.

In multivariate logistic regression analysis, where $\mathrm{CO}$ poisoning (severe versus moderate/mild) was the dependent variable and age group, $\mathrm{HbCO}$ level and interaction term (age groups $x$ HbCO level) were independent variables, a $1 \%$ increase in $\mathrm{HbCO}$ slightly increased the odds of having severe $\mathrm{CO}$ poisoning (adjusted $\mathrm{OR}=1.05 ; 95 \% \mathrm{CI}$ : 1.02-1.08).

\section{Discussion}

$\mathrm{CO}$ poisoning from heaters is a serious risk of death and disability in Turkey

\begin{tabular}{|c|c|c|c|c|c|c|c|}
\hline \multirow[t]{2}{*}{ Variable } & \multicolumn{2}{|c|}{$\begin{array}{c}\text { Severe } \\
(\mathrm{GCS} \leq 12)\end{array}$} & \multicolumn{2}{|c|}{$\begin{array}{l}\text { Moderate } \\
\text { (GCS 13-14) }\end{array}$} & \multicolumn{2}{|c|}{$\begin{array}{c}\text { Mild } \\
(\mathrm{GCS} \geq 15)\end{array}$} & \multirow[t]{2}{*}{$P$-value } \\
\hline & No. & $\%$ & No. & $\%$ & No. & $\%$ & \\
\hline \multicolumn{8}{|l|}{ Source of CO } \\
\hline Coal heater & 66 & 25.2 & 33 & 12.6 & 163 & 62.2 & $0.042^{\mathrm{a}}$ \\
\hline Liquefied gas heater & 16 & 39.0 & 8 & 19.5 & 17 & 41.5 & \\
\hline \multicolumn{8}{|l|}{ Age group(years) } \\
\hline 14-19 & 8 & 21.6 & 9 & 24.3 & 20 & 54.1 & $0.001^{\mathrm{a}}$ \\
\hline $20-29$ & 19 & 21.6 & 16 & 18.2 & 53 & 60.2 & \\
\hline $30-39$ & 18 & 28.1 & 4 & 6.3 & 42 & 65.6 & \\
\hline $40-49$ & 12 & 26.1 & 2 & 4.3 & 32 & 69.6 & \\
\hline $50-59$ & 6 & 18.2 & 7 & 21.2 & 20 & 60.6 & \\
\hline \multirow[t]{2}{*}{$\geq 60$} & 20 & 54.1 & 4 & 10.8 & 13 & 35.1 & \\
\hline & No. & $\begin{array}{l}\text { Median } \\
\text { (i/q range) }\end{array}$ & No. & $\begin{array}{l}\text { Median } \\
\text { (i/q range) }\end{array}$ & No. & $\begin{array}{l}\text { Median } \\
\text { (i/q range) }\end{array}$ & \\
\hline Blood HbCO level (\%) & 42 & $\begin{array}{c}27.5 \\
(16.5-39.0)\end{array}$ & 24 & $\begin{array}{c}23.0 \\
(14.3-28.8)\end{array}$ & 122 & $\begin{array}{c}18.0 \\
(12.8-26.0)\end{array}$ & $0.002^{\mathrm{b}}$ \\
\hline $\begin{array}{l}\text { Duration of ICU stay } \\
\text { (days) }\end{array}$ & 57 & $\begin{array}{c}7.0 \\
(2.5-16.0)\end{array}$ & 10 & $\begin{array}{c}2.5 \\
(2.0-4.3)\end{array}$ & 7 & $\begin{array}{c}3.0 \\
(2.0-6.0)\end{array}$ & $0.004^{\mathrm{b}}$ \\
\hline
\end{tabular}

${ }^{a}$ Pearson chi-squared test.

${ }^{b}$ Kruskal-Wallis test.

$\mathrm{HbCO}=$ carboxyhaemoglobin; $i / q=$ interquartile; $I C U=$ intensive care unit. 


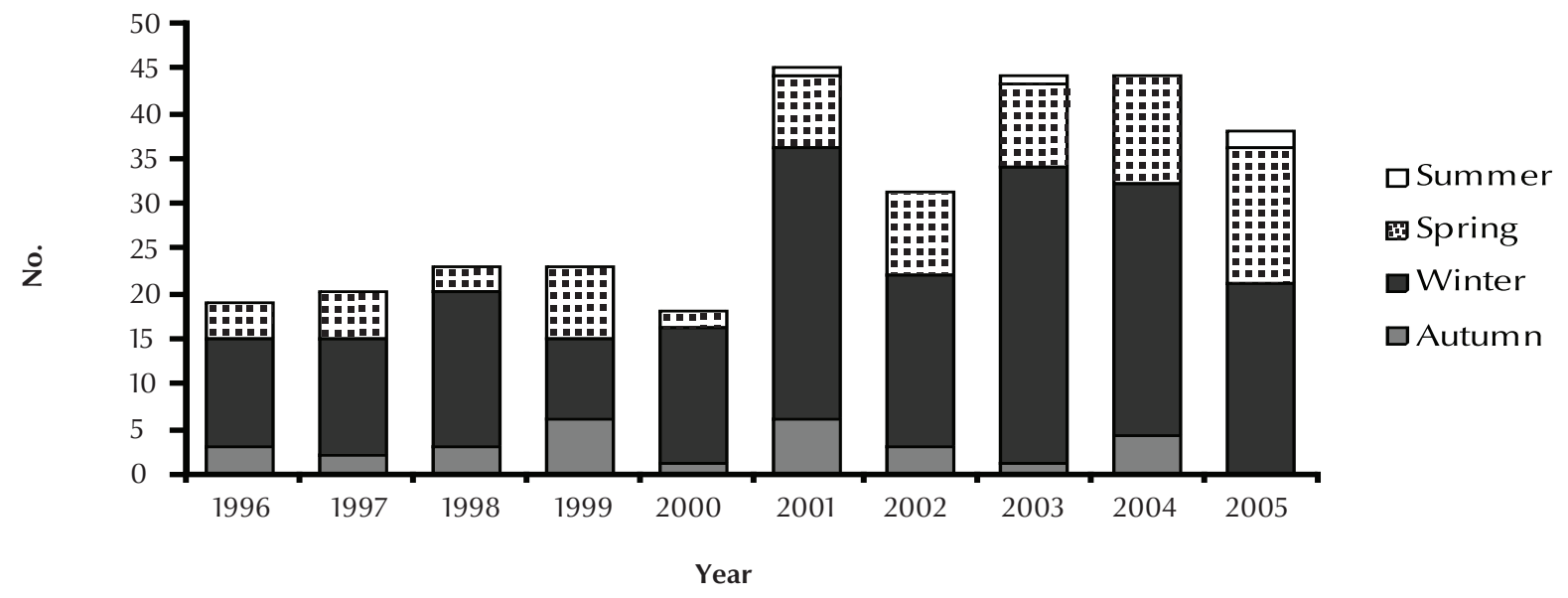

Figure 1 Annual and seasonal distribution of cases of carbon monoxide (CO) poisoning $(n=305)$

especially in the winter months. Incomplete burning of coal, for example in small heaters with an inadequate chimney system, results in the formation of $\mathrm{CO}$ which can cause poisoning. Lack of public safety information and inadequate regulations are responsible for $\mathrm{CO}$ poisoning from heaters [3-6]. In our country, $\mathrm{CO}$ poisoning occurs in particular cities including Bursa [8,9]. In Bursa, south-east winds, which are particularly strong in late December, January and February, blow through the chimneys and cause regurgitation of the exhaust gases into the houses.

The majority of the $\mathrm{CO}$ poisoning cases in our study occurred in the winter $(64.6 \%)$. This is in accordance with the literature [10-12]. The use of coal heaters in the winter months and the strong south-east winds contribute to the increased number of cases.

Our study covered a 10-year period. The number of recorded admissions increased every year, despite the serious efforts in public education, particularly in the last 5 years. The Department of Health, Uludağ University Medical School and various nongovernmental organizations issue warnings, in the form of public meetings, reports in the written and visual media and websites, especially in the winter months and days of the strong south-east wind. However, the apparent increase in cases in recent years may be an artefact due to the inadequacy of the older records, the development of intensive care facilities in our institutions and increased referral of the poisoning cases to the university hospital.

The present study included 305 patients. The proportion of women (57.0\%) was significantly higher than men (43.0\%). Other published studies reported equal frequencies or a predominance of men [10-16]. A predominance of men may be due to the workplace fires and suicide attempts. In our study, the majority of the $\mathrm{CO}$ poisonings (99.3\%) occurred at home.

CO poisoning is ubiquitous worldwide. It is a commonly encountered poison in accidents, such a smoke from fires, vehicle exhaust fumes in closed garages and generators used in poorly ventilated areas, and in suicide attempts $[11,12,14,16,17]$. Operation of vehicles in closed garages is a method of suicide in some countries $[16,18]$. In the present study, almost all the patients were accident victims and there was only 1 known case of suicide. It is possible that other methods are used more frequently in suicide attempts in this region (e.g. ingestion of poison) [7].

According to the GCS at admission, $59.0 \%$ had mild CO poisoning, $13.4 \%$ had moderate and $27.2 \%$ had severe poisoning. In a 5-year study in France, $80.9 \%$ of patients had mild poisoning, $14.4 \%$ moderate poisoning and $34.7 \%$ had severe poisoning [11]. Of our 305 patients with CO poisoning, 10 (3.3\%) died. The mortality reported in other studies varied between $2.6 \%$ and $9.8 \%$ $[1-3,9]$, so our rate is in the same range.

The affinity of CO to haemoglobin is approximately 240 times that of oxygen. Consequently, $\mathrm{CO}$ blocks transport of oxygen by haemoglobin to the tissues by inducing a state of asphyxia. Symptoms such as fatigue and headache typically occur when the $\mathrm{HbCO}$ level exceeds $20 \%$; levels above $40 \%$ cause loss of consciousness and convulsions, while levels above $60 \%$ may be lethal $[19,20]$. Nevertheless, the effects of particular levels are subject to variation due to personal and environmental factors such as haemoglobin level, age, physical activity, metabolic rate, history of cardiovascular and/or systemic disease, and degree and duration of exposure to $\mathrm{CO}[13,19,20]$. The $\mathrm{HbCO}$ level was measured in $61.6 \%$ of our CO poisoning cases $(n=188)$. 
Intermittent equipment failure is the reason for the missing measurements. There was a statistically significant but weak negative relationship between the $\mathrm{HbCO}$ level and age.

The GCS showed statistically highly significant but weak negative relationships with duration of mechanical ventilation, ICU stay and $\mathrm{HbCO}$ levels. Patients with lower GCS had longer periods of mechanical ventilation, ICU stay and higher $\mathrm{HbCO}$ levels. Among patients aged $60+$ years, $54.1 \%$ suffered severe $\mathrm{CO}$ poisoning, whereas in other age groups this ranged from $18.2 \%$ to $28.1 \%$. The determinants of severity, morbidity and mortality in $\mathrm{CO}$ poisoning in other studies were patient's age, cardiovascular co-morbidity and duration of exposure $[13,19,20]$. Our study confirmed a statistically significant association between age and severity of CO poisoning. After the effect of age was controlled for in multivariable analysis, a higher $\mathrm{HbCO}$ level was associated with more severe $\mathrm{CO}$ poisoning.

Liquefied gas sources were more dangerous than coal heaters in relation to the severity of the $\mathrm{CO}$ poisoning. This may be explained by the fact that in those instances, victims are exposed to higher concentrations of $\mathrm{CO}$ in a shorter period. Because the half-life of carboxyhaemoglobin is approximately 250 minutes, breathing for a few minutes in an atmosphere containing $0.1 \% \mathrm{CO}$, will lead to the formation of $50 \% \mathrm{HbCO}$ in the blood [13,19]. In coal heater poisonings, victims are exposed to lower concentrations of $\mathrm{CO}$ for longer periods.

Poisoning due to CO leaks from coal heaters is a common problem in our country and surrounding regions. The elderly population is at a higher risk. Various institutions are expending efforts to educate the public and prevent $\mathrm{CO}$ poisoning. However, these are inadequate. Extensive use of $\mathrm{CO}$ detectors, widespread intensive education and monitoring of equipment that may emit $\mathrm{CO}$ will prevent most of these poisonings.

\section{References}

1. Cobb N, Etzel RA. Unintentional carbon monoxide-related deaths in the United States, 1979 through 1988. Journal of the American Medical Association, 1991, 266:659-63.

2. Weaver LK. Carbon monoxide poisoning. Critical care clinics, 1999, 15:297-317.

3. Aksoy E, Polat O, İnanıcı MA. [Retrospective analysis of 293 carbon monoxide poisoning cases.] Clinical development, 1995, 8:3545-9 [in Turkish].

4. Türkmen N, Akgöz S. [Carbon monoxide intoxication related deaths autopsies in Bursa.] Journal of forensic medicine, 2005, 19:20-5 [in Turkish].

5. Salaçin S. Acute carbon monoxide intoxications due to simple and preventable fatal accidents. American journal of forensic medicine and pathology, 1991, 12:191-3.

6. Azmak D et al. [Carbon monoxide-related deaths.] Journal of forensic medicine, 1994, 10:73-81 [in Turkish].

7. Akköse Ş et al. Acute poisoning in adults in the years 1996-2001 treated in the Uludağ University Hospital, Marmara region. Turkey. Clinical toxicology, 2005, 43:105-9.

8. 2000 census of population: social and economic characteristics of population of Bursa province. Ankara, Turkey, State Institute of Statistics Printing Division, 2002.

9. Genel istatistikler. Bursa Sağlık Müdürlüğü [General statistics. Bursa Health Department] [website] (http://www.bsm.gov.tr/ istatistik, accessed 26 May 2009).

10. Ministry of Health, Turkey [website] (http://www.saglik.gov.tr, accessed 26 May 2009).

11. Lıu K et al. Unintentional carbon monoxide deaths in California from residential and other nonvehicular sources. Archives of environmental health, 2000, 55:375-81.
12. Sam-Laï NF, Saviuc P, Danel V. Carbon monoxide poisoning monitoring network: a five-year experience of household poisonings in two French regions. Journal of toxicology, Clinical toxicology, 2003, 41(4):349-53.

13. Bowen $\mathrm{D}$ et al. Carbon monoxide poisoning. Forensic science international, 1989, 41:163-8.

14. Satran D et al. Cardiovascular manifestations of moderate to severe carbon monoxide poisoning. Journal of the American College of Cardiologists, 2005, 45(9):1513-6.

15. Homer $\mathrm{CD}$ et al. Carbon monoxide-related deaths in a metropolitan county in the USA: an 11-year study. Forensic science international, 2005, 149:159-65.

16. Handa PK, Tai DYH. Carbon monoxide poisoning: a five-year review at Tan Tock Seng Hospital, Singapore. Annals of the Academy of Medicine of Singapore, 2005, 34:611-4.

17. McDowell R, Fowles J, Phillips D. Deaths from poisoning in New Zealand: 2001-2002. New Zealand medical journal, 2005, 11: 118:U1725.

18. Unintentional non-fire-related carbon monoxide exposuresUnited States, 2001-2003. Morbidity and mortality weekly report, 2005, 54(2):36-9.

19. Dolan MC. Carbon monoxide poisoning. Canadian Medical Association journal, 1985, 133:392-9.

20. Olson KR. Carbon monoxide poisoning mechanisms presentations and controversies in management. Journal of emergency medicine, 1984, 1:233-43. 